\title{
Urgensi Pengaturan Peredaran Minuman Beralkohol di Daerah Istimewa Yogyakarta
}

\author{
Ni'matul Huda, Jamaludin Ghafur, dan Ali Ridho \\ Fakultas Hukum Universitas Islam Indonesia \\ Jl. Tamansiswa No. 158 Yogyakarta \\ james.fhuii@gmail.com.
}

\begin{abstract}
This study discusses the urgency of setting up the circulation of alcoholic beverages in DIY formulated in the following three research problems: first, what is the urgency of Yogyakarta Province government in regulating the circulation of alcoholic drinks? Second, what is the basic principles underlying Yogyakarta Province authority to regulate the circulation of alcoholic beverages and what is the best form of legal products to regulate the circulation of alcoholic beverages in the province? Third, what are the materials of the regulations on the distribution of alcoholic beverages in Yogyakarta Province? This research is a normative juridical which uses primary law, secondary law, and tertiary legal materials. The results showed that first, urgency settings of alcoholic beverages is intended as prevention (preventive), risk reduction (preparedness), responsiveness (response), as well as recovery efforts (recovery) from drinking alcoholic beverages. Secondly, the basis of the authority of Yogyakarta Province Government for the Distribution of Alcoholic Beverages regulation is rooted in Law 32 of 2004 and Presidential Decree No. 74 Year 2014. Third, the main points of the materials contain (i) the type and classification of alcoholic beverages; (ii) a ban on the production, distribution, sale and storage of alcoholic beverages; (iii) licensing; (iv) community participation.
\end{abstract}

Keywords: Regional regulation, circulation, alcoholic beverages, and the authority

\begin{abstract}
Abstrak
Penelitian ini membahas urgensi pengaturan peredaran minuman beralkohol di DIY yang dirumuskan dalam tiga rumusan masalah yakni: pertama, apa urgensi pemerintah DIY mengatur peredaran minuman beralkohol? Kedua, apa dasar kewenangan DIY dalam mengatur peredaran minuman beralkohol dan dalam bentuk produk hukum apakah seharusnya peredaran minuman beralkohol di DIY itu diatur? Ketiga, apa sajakah materi muatan peraturan tentang peredaran minuman beralkohol DIY tersebut? Penelitian ini adalah penelitian yuridis normatif, dengan menggunakan bahan hukum primer, bahan hukum sekunder, dan bahan hukum tersier. Hasil penelitian menunjukkan pertama, urgensi pengaturan minuman beralkohol dimaksudkan sebagai pencegahan (preventive), pengurangan resiko (preparedness), daya tanggap (response), serta upaya pemulihan (recovery) akibat minum minuman beralkohol. Kedua, dasar kewenangan Pemerintah DIY mengatur Peredaran Minuman Beralkohol bersumber pada UU No. 32 tahun 2004 dan Peraturan Presiden No. 74 Tahun 2014. Ketiga, pokok-pokok materi muatannya (i) jenis dan klasifikasi minuman beralkohol; (ii) larangan produksi, peredaran, penjualan, dan penyimpanan minuman beralkohol; (iii) perizinan; (iv) peran serta masyarakat.
\end{abstract}

Kata kunci: Peraturan Daerah, peredaran, minuman beralkohol, dan kewenangan. 


\section{Pendahuluan}

Maraknya peredaran dan penyalahgunaan minuman beralkohol di Indonesia -tidak terkecuali di DIY- telah menimbulkan berbagai macam persoalan, bukan hanya terhadap individu peminum, namun juga telah meresahkan masyarakat secara umum. Kasus teraktual tentang dampak negatif minuman beralkohol adalah meninggalnya 14 orang akibat mengkonsumsi minuman beralkohol di Pasar Minggu, Jakarta Selatan pada 13 Oktober 2013. ${ }^{1}$

Menurut data, minuman keras atau minuman beralkohol telah menjadi pemicu berbagai macam kejahatan yaitu sebanyak $65-70 \%$ tindak kriminalitas terjadi akibat mabuk minuman keras. Selain itu, sekitar 15\% kecelakaan lalu lintas juga akibat dari pengaruh minuman keras. ${ }^{2}$ Dalam konteks DIY, peredaran minuman beralkohol yang tidak terkontrol ini telah menyebabkan aksi premanisme seperti pengeroyokan, pemerasan dan penganiayaan, ${ }^{3}$ bahkan menjadi penyebab bentrokan. Seperti yang terjadi pada Sabtu, 31 Agustus 2013 dini hari di Kalasan Sleman. Bentrokan tersebut diduga disebabkan oleh adanya seorang warga yang dipukul oleh salah seorang anggota ormas, yang diduga sedang dalam pengaruh minuman keras. Insiden tersebut, kemudian menyulut terjadinya bentrokan dan saling lempar batu maupun kayu antar dua kelompok. ${ }^{4}$

Aksi-aksi kejahatan yang diakibatkan oleh pengaruh minuman beralkohol tersebut disebabkan karena sifat dari minuman tersebut yang apabila dikonsumsi secara berlebihan akan menyebabkan tidak sadar diri dengan berbagai efek tubuh seperti muntah-muntah, tertidur, mabuk dengan melakukan berbagai gangguan yang merugikan kehidupan masyarakat, seperti gangguan terhadap lalu lintas dengan berbagai akibatnya, kriminalitas, dan sebagainya. Sehingga, secara kriminologis, pecandu alkohol (alkoholisme) merupakan faktor kriminogen atau

${ }^{1}$ Koran Tempo, Jum'at, 23 Agustus 2013

${ }^{2}$ Tri Sugiarti; "Pencabutan Perda Miras: Melanggengkan Kemaksiatan”, dalam www.detiknews.com, diakses 1 Juni 2014.

3"Pengaruh Miras Picu Aksi Premanisme", dalam http://jogja.okezone.com/read/2013/04/12/510/ 790525/redirect, diakses 14 Juni 2014.

4"Bentrok Warga Vs Ormas", dalam http:// www.jogjatv.tv/berita/31/08/2013/bentrok-warga-vs-ormas, diakses 14 Juni 2014. 
penyebab timbulnya aneka kejahatan. ${ }^{5}$ Minuman beralkohol adalah minuman yang mengandung ethanol, bahan psikoaktif yang menyebabkan berkurangnya kesadaran jika dikonsumsi. Oleh karena itu, di berbagai negara penjualan minuman beralkohol dibatasi ke sejumlah kalangan saja, umumnya orang-orang yang telah melewati batas-batas usia tertentu. ${ }^{6}$

Sebagai upaya untuk mengantisipasi kemungkinan terjadinya hal-hal yang tidak diinginkan terkait langsung dengan keberadaan minuman beralkohol ini, pemerintah sudah membuat aturan guna mengawasi dan mengendalikan peredarannya, seperti: Keputusan Presiden Nomor 3 Tahun 1997 tentang Pengawasan dan pengendalian Minuman Beralkohol, Peraturan Menteri Perdagangan Nomor 45/M-DAG/PER/12/2010, Jo Peraturan Menteri Perdagangan Nomor 20/M-DAG/PER/7/2011, Jo Peraturan Menteri Perdagangan Nomor 11/MDAG/PER/3/2012, Jo Peraturan Menteri Perdagangan Nomor 53/MDAG/PER/12/2012 tentang Ketentuan Pengadaan, Pengedaran, Penjualan, Pengawasan, dan Pengendalian Minuman Beralkohol dan Peraturan Menteri Perdagangan Republik Indonesia Nomor: 15/M-DAG/PER/3/2006 tentang Pengawasan dan Pengendalian Impor, Pengedaran dan Penjualan, dan Perizinan Minuman Beralkohol.

Secara keseluruhan, beberapa perangkat peraturan hukum di atas sebenarnya sudah cukup memadai dalam rangka mengatur peredaran minuman beralkohol di Indonesia. Namun, pada Juli 2013 Keputusan Presiden (Keppres) Nomor 3 Tahun 1997 yang selama ini menjadi peraturan induk bagi pengawasan dan pengendalian minuman beralkohol di Indonesia telah dibatalkan dan dinyatakan tidak berlaku lagi oleh Mahkamah Agung melalui permohonan judicial review yang diajukan oleh Front Pembela Islam (FPI). Konsekuensinya, menurut teori peraturan perundang-undangan, seluruh peraturan di bawahnya yang pembentukannya berlandaskan pada Keppres tersebut (seperti Peraturan Menteri Perdagangan) secara otomatis juga tidak memiliki kekuatan hukum yang mengikat.

${ }^{5}$ Soedjono Dirdjosisworo, Alkoholisme: Paparan Hukum dan Kriminologi, Penerbit Remadja Karya, Bandung, 1984, hlm. 145

${ }^{6}$ Lihat dalam www.wikipedia.com, diakses 14 Juni 2014. 
Pada tahun 2013, Presiden menetapkan Peraturan Presiden Republik Indonesia Nomor 74 Tahun 2013 tentang Pengendalian dan Pengawasan Minuman Beralkohol sebagai revisi atas Keputusan Presiden Nomor 3 Tahun 1997 tentang Pengawasan dan Pengendalian Minuman Beralkohol yang dinyatakan tidak sah dan tidak mempunyai kekuatan hukum oleh Putusan Mahkamah Agung Nomor $42 \mathrm{P} / \mathrm{HUM} / 2012$. Namun demikian, keluarnya perpres tersebut belum memadai untuk dijadikan satu-satunya regulasi dalam pengaturan peredaran minuman beralkohol di DIY sebab isi perpres tersebut masih sangat umum. Oleh sebab itu, kehadiran peraturan di tingkat daerah tentang peredaran minuman beralkohol di DIY yang memuat dan mengatur halhal spesifik sesuai kebutuhan dan karakteristik DIY masih sangat relevan.

Selain itu, di level kabupaten dan kota di DIY seluruhnya telah memiliki peraturan daerah tentang peredaran minuman beralkohol, namun sayang, di Provinsi DIY justru sampai saat ini belum memilikinya. Padahal menurut Undang-Undang Nomor 12 Tahun 2011 tentang Pembentukan Peraturan Perundang-Undangan, kedudukan perda provinsi terhadap perda kabupaten dan/atau kota adalah bersifat hirarkis.

\section{Rumusan Masalah}

Berdasarkan pada permasalahan di atas, menarik untuk meneliti terkait urgensi pengaturan peredaran minuman beralkohol di DIY yang dirumuskan dalam tiga rumusan masalah sebagai berikut: pertama, apa urgensi pemerintah DIY mengatur peredaran minuman beralkohol?; Kedua, apa dasar kewenangan DIY dalam mengatur peredaran minuman beralkohol dan dalam bentuk produk hukum apakah seharusnya peredaran minuman beralkohol di DIY itu diatur?; Ketiga, apa sajakah materi muatan peraturan tentang peredaran minuman beralkohol DIY tersebut? 


\section{Tujuan Penelitian}

Tujuan penelitian adalah pertama, meneliti urgensi pemerintah DIY mengatur peredaran minuman beralkohol. Kedua, mengetahui dasar kewenangan pemerintah DIY dalam mengatur peredaran minuman beralkohol dalam bentuk produk hukum. Ketiga, mengetahui materi muatan peraturan tentang peredaran minuman beralkohol DIY.

\section{Metode Penelitian}

Penelitian ini lebih menitik beratkan pada penelitian yuridis normatif, dengan melihat, mempelajari, dan memahami materi hukum, terutama normanorma yang mengatur tentang kewenangan pemerintah daerah dalam membuat peraturan perundang-undangan. Oleh karena itu, sumber data yang digunakan adalah data sekunder yang terdiri dari bahan hukum primer, bahan hukum sekunder, dan bahan hukum tersier. Data yang terkumpul kemudian dianalisis secara diskriptif kualitatif.

\section{Hasil Penelitian dan Pembahasan}

\section{Urgensi Pemerintah Daerah Istimewa Yogyakarta Mengatur Peredaran Minuman Beralkohol}

Secara sosiologis, urgensi pengaturan minuman beralkohol tidak lain dimaksudkan sebagai jawaban atau solusi terhadap permasalahan yang berkaitan dengan penanganan bahaya yang diakibatkan oleh minuman beralkohol. Oleh karena itu, fokus dari pengaturan tersebut adalah untuk melakukan pencegahan (preventive), pengurangan resiko (preparedness), daya tanggap (response), serta upaya pemulihan (recovery) akibat minum minuman beralkohol.

Terhadap peredaran dan dampak minuman keras atau alkohol di DIY, misalnya pada bulan Januari 2014, di bulan tersebut ada sekitar 629 botol miras serta 5 jerigen miras oplosan berhasil disita. Dari jumlah tersebut, 440 botol di 
antaranya merupakan miras impor yang diduga palsu. ${ }^{7}$ Adapun jika dilihat jumlah korban atas peredaran minuman beralkohol atau minuman keras illegal, dari 2013-Juli 2014 setidaknya telah terdapat 30 orang yang meninggal akibat minuman keras. 8 Dampak lain terhadap konsumsi atas minuman berlakohol dalam jumlah yang berlebihan juga dapat menyebabkan intoksikasi akut yang bisa memacu kecelakaan dan kriminalitas. Hal itu terbukti misalnya dengan melihat kasus yang terjadi pada maret 2014 dimana terdapat dua kasus kriminal yang terjadi di wilayah hukum Polresta Jogja karena dipicu oleh minuman keras. ${ }^{9}$

Kenyataan lain, juga terlihat bahwa di Yogyakarta peredaran minuman beralkohol begitu sangat mudah dan longgar dan minim segi pengawasannya, sehingga dapat memudahkan siapa pun untuk memperolehnya. Salah satu indikasinya adalah dengan menjamurnya toko retail modern di Yogyakarta yang menjual minuman beralkohol golongan A. Data dari Gerakan Nasional Anti Miras (Genam) Chapter Yogyakarta menyebutkan bahwa 80\% toko retail modern menjual aneka macam kadar minuman beralkohol. Banyaknya jasa penjualan minuman beralkohol tersebut yang kemudian memudahkan remaja, khususnya pelajar untuk dapat mengonsumsinya. Terlebih lagi toko tersebut menyediakan tempat khusus untuk bersantai. ${ }^{10}$

Selanjutnya, apabila melihat animo masyarakat Yogyakarta khususnya yang telah berumur 15 tahun ke atas terhadap reliabilitas untuk jenis minuman beralkohol yang biasa diminum dapat dilihat pada tabel sebagai berikut:

7 Peredaran Miras Impor Palsu Marak di Jogja, dalam http://sorotjogja.com/berita-jogja-3456-peredaranmiras-impor-palsu-marak-di-jogja.html, diakses 14 Agustus 2014.

8 Data diambil dari berbagai sumber, misalnya lihat Pesta Miras Oplosan, 8 Warga Yogyakarta Tewas, dalam http://nasional.news.viva.co.id/news/read/128058-pesta_miras_oplosan_8_warga_yogyakarta_tewas, diakses tanggal 14 Agustus 2014.

9 Dua Tewas akibat Kasus Kriminal di Jogja yang Dipicu Miras, dalam http://www.harianjogja. com/baca/2014/03/20/dua-tewas-akibat-kasus-kriminal-di-jogja-yang-dipicu-miras-497479, diakses tanggal 15 Agustus 2014. Selanjutnya ketergantungan terhadap alkohol akan menimbulkan masalah disrupsi keluarga, disintegrasi sosial dan penurunan produktivitas, sehingga mengakibatkan kerugian sosial ekonomi bagi masyarakat dan Negara. Lihat Suhardi, "Preferensi Peminum Alkohol Di Indonesia Menurut Riskesdas 2007", Jurnal Kesehatan, Volume 39, No. 4, 2011, hlm. 155.

${ }^{10}$ Toko Retail Modern Permudah Remaja Jogja Konsumsi Alkohol, dalam http://beritajogja.co.id/2014 L02/21/toko-retail-modern-permudah-remaja-jogja-konsumsi-alkohol/, diakses tanggal 15 Agustus 2014. 
Tabel 1

Proporsi jenis alkohol yang diminum penduduk laki-laki 15 Tahun ke atas menurut provinisi di Indonesia 2013 (5 besar provinsi)

\begin{tabular}{|c|l|r|r|r|r|r|}
\hline \multirow{2}{*}{ No } & \multicolumn{1}{|c|}{ Provinsi } & \multicolumn{4}{|c|}{ Jenis Minuman Beralkohol (\%) } \\
\cline { 3 - 7 } & & \multicolumn{1}{|c|}{ Bir } & Likuor & Wine & \multicolumn{1}{|c|}{ Trad } & \multicolumn{1}{c|}{ Total } \\
\hline 1 & DKI Jakarta & 37,9 & 10,8 & 41,4 & 9,9 & 100 \\
2 & Jawa Barat & 34,1 & 11,4 & 44,8 & 9,8 & 100 \\
3 & Jawa Tengah & 32,8 & 13,3 & 44,6 & 9,3 & 100 \\
4 & Jawa Timur & 34,2 & 24,8 & 23,7 & 17,3 & 100 \\
5 & DI Yogyakarta & 18.2 & 26,5 & 53,5 & 1,8 & 100 \\
\hline
\end{tabular}

Sumber: Suhardi, 2013.

Beberapa kenyataan sosiologis seperti yang teruraikan di atas, maka bisa menjadi bahan pijakan dalam merumuskan sebuah kebijakan antisipatif pencegahan dan penanganan peredaran, dan dampak dari minuman beralkohol di Yogyakarta, mengingat Pemda DIY yang belum memiliki Perda khusus yang mengatur pembatasan miras.

Sebuah kebijakan akan bermuara pada sebuah keteraturan bilamana diproses dan dirumuskan atas dasar nilai-nilai yang terkandung dalam suatu daerah tertentu. Nilai tersebut, dapat berupa kearifan lokal suatu daerah atau nilai budaya yang telah menjadi bagian dari sebuah sistem di daerah. Hal ini mengingat dalam sistem nilai, sebagai inti dari sistem budaya, menjiwai semua pedoman yang mengatur tingkah laku warga pendukung kebudayaan yang bersangkutan. Pedoman tingkah laku itu adalah adat istiadatnya, sistem norma, aturan etika, aturan moral, aturan sopan santun, pandangan hidup dan ideologi pribadi. ${ }^{11}$ Berangkat atas hal tersebut, maka semakin penting bahwa bangunan kebijakan, khususnya kebijakan di DIY harus didasarkan pada sistem nilai atau kearifan lokal yang telah tumbuh berkembang bertahun-tahun. ${ }^{12}$

11 Mattulada, Sejarah Masyarakat dan Kebudayaan Sulawesi Selatan, Hasanuddin University Press, Makasar, 1991, hlm. 2-4.

${ }^{12}$ Dalam ilmu antropologi kearifan lokal dikenal juga istilah dengan local genius. Local genius ini merupakan istilah yang pertama dikenalkan oleh Quaritch Wales. Para antropolog membahas secara panjang lebar pengertian local genius ini. Antara lain bahwa local genius adalah juga cultural identity, identitas/kepribadian budaya bangsa yang menyebabkan bangsa tersebut mampu menyerap dan mengolah kebudayaan asing sesuai watak dan kemampuan sendiri. Lihat Ayatrohaedi, Kepribadian Budaya Bangsa (local Genius), Pustaka Jaya, Jakarta, 1986, hlm. 18-19. Sementara Menurut Moendardjito mengatakan bahwa unsur budaya daerah potensial sebagai local genius karena telah teruji kemampuannya untuk bertahan. Adapun ciri-cirinya adalah sebagai berikut: 1. mampu bertahan terhadap budaya luar; 2. memiliki kemampuan mengakomodasi unsur-unsur budaya luar; 3. mempunyai kemampuan mengintegrasikan unsur budaya luar ke dalam budaya asli; 4. mempunyai kemampuan mengendalikan 5. mampu memberi arah pada perkembangan budaya. Lihat Moendardjito, Negara Yang 
Apabila dilihat secara mendasar, letak kearifan lokal yang ada di DIY setidaknya meliputi empat aspek, yaitu: 1). nilai etika moral; 2). nilai estetika; 3). nilai sosial-kemasyarakatan; dan 4). nilai religio-spiritual ${ }^{13}$. Nilai-nilai kearifan lokal tersebut dapat diuraikan, pertama nilai etika moral ${ }^{14}$. Nilai etik atau etis sering disebut sebagai nilai moral, akhlak, atau budi pekerti. Nilai tersebut dapat dideskripsikan bahwa masyarakat DIY memiliki sikap untuk menilai baik buruknya sebuah tindakan, fenomena dan keadaan. Dalam etika masyarakat Yogyakarta, telah tertanam patern of behavior seperti mengenai masalah predikatpredikat nilai 'betul' atau 'salah', 'susila' dan 'tidak susila'. Dalam konteks yang lebih detail, nilai moral yang mudah dijumpai di Yogyakarta misalnya, sopan dalam bertutur kata.

Kedua, nilai estetika atau nilai keindahan. Estetika bisa diartikan sebagai ekspresi ruh dan budaya manusia yang mengandung dan mengungkapkan keindahan. ${ }^{15}$ Nilai estetik masyarakat Yogyakarta bisa dilihat dari peninggalan benda-benda bersejarah. Benda-benda budaya bersejarah itu merepresentasikan peradaban dan kejayaan di masa pembuatannya, memberi informasi tentang latar belakang budaya masa lalu, dan meninggalkan pesan kearifan bagi kehidupan manusia masa kini. Keindahan benda-benda peninggalan bersejarah, memberi pesan dan maksud bahwa dalam menjalani kehidupan, masyarakat Yogyakarta dituntut untuk senantiasa mengikuti tradisi keindahan yang telah diwariskan

Demokratis, Yayasan Koridor Pengabdian, Jakarta, 1986, hlm. 40-41. Kemudian Sartini mengatakan bahwa kearifan lokal (local genius) adalah kebenaran yang telah mentradisi atau ajeg dalam suatu daerah. Kearifan lokal merupakan perpaduan antara nilai-nilai suci firman Tuhan dan berbagai nilai yang ada. Lihat Sartini, Menggali Kearifan Lokal Nusantara Sebuah Kajian Filsafati, Penerbit Air Langga, Jakarta, 2003, hlm. 111.

13 Sementara menurut Wagiran, dalam lingkup DIY, kajian tentang kearifan lokal dapat dikaji dari filosofi nilai budaya kraton yang meliputi: Pohon, Bangunan, Pemerintahan, Konsep kekuasaan, kepemimpinan, Simbolisme Binatang, Simbol Vegetasi, Simbol senjata, dan Sengkalan. Sedangkan dari sisi budaya, secara komprehensif dapat dicermati dari tata nilai budaya Yogyakarta yang meliputi aspek: (1) religio-spiritual, (2) moral, (3) kemasyarakatan, (4) adat dan tradisi, (5) pendidikan dan pengetahuan, (6) teknologi, (7) penataan ruang dan arsitektur, (8) mata pencaharian, (9) kesenian, (10) bahasa, (11) benda cagar budaya dan kawasan cagar budaya, (12) kepemimpinan dan pemerintahan, (13) kejuangan dan kebangsaan, dan (14) semangat khas keyogyakartaan. Lihat Wagiran, "Pengembangan Model Pendidikan Kearifan Lokal Dalam Mendukung Visi Pembangunan Provinsi Daerah Istimewa Yogyakarta 2020 (Tahun Kedua)", Jurnal Penelitian dan Pengembangan, Volume III, Nomor 3, Tahun 2011, hlm. 4.

${ }^{14}$ Nilai moral menurut Ouska dan Whellan mengartikan moral sebagai prinsip baik-buruk yang ada dan melekat dalam diri seseorang. Namun demikian, walaupun moral itu berada di dalam diri individu tetapi moral berada dalam suatu sistem yang berwujud aturan. Moral dan moralitas merupakan dua konsep yang berbeda. Moral adalah prinsip baik-buruk sedangkan moralitas merupakan kualitas pertimbangan baik-buruk. Dengan demikian, hakekat dan makna moralitas dapat dilihat dari cara individu yang memiliki moral dalam mematuhi maupun menjalankan aturan. Lihat Ruminiati, Modul Pendidikan Kewarganegaraan SD: Untuk Program S1 PJJ., Dirjen Dikti, Depdiknas R.I, Jakarta, 2007, hlm. 32.

${ }^{15}$ Qurais Shihab, Islam dan Kesenian, Litbang PP Muhammadiyah, Yogyakarta, 1995, hlm. 3. 
nenek moyangnya. Warisan estetis tersebut yang telah menjadikan masyarakat Yogyakarta senantiasa memiliki cita-cita mulia yakni menjaga kebenaran, kebaikan, keindahan, dan kelestarian dunia (hamemayu hayuning bawana). Maka dari itu, setiap tindakan yang dilakukan oleh masyarakat Yogyakarata senantiasa percaya diri (sengguh) dan bertanggung jawab dengan siap menanggung segala risiko (ora mingkuh).

Ketiga, nilai sosial-kemasyarakatan. Masyarakat DIY telah lama mengedepankan kekeluargaan dan kasih sayang antar sesama ((sih kinasihan; asih ing sesami) dalam berinteraksi. Dianutnya model kehidupan yang demikian tidak lain karena keinginan masyarakatnya untuk senantiasa hidup dalam kerukunan. Kerukunan merupakan tiang utama kehidupan bermasyarakatnya, sehingga kerukunan memberikan kekuatan, sedangkan pertikaian mendatangkan kehancuran (rukun agawé santosa, crah agawé bubrah). Apabila timbul persoalan di antara anggota masyarakat, maka harus diselesaikan sebaik-baiknya dengan bermusyawarah secara kekeluargaan (ana rembug ya dirembug). ${ }^{16}$ Oleh karena itu, adanya aktivitas yang bisa merugikan karena disebabkan pengaruh zat memabukkan seperti minuman beralkohol menjadi penting untuk dilakukan pengaturan, tujuannya tidak lain supaya kelestarian local wisdom masyarakat Yogyakarta senantiasa membumi dan bisa berjalan dengan baik.

Keempat, nilai religio-spiritual. Nilai keagamaan masyarakat Yogyakarta secara garis besar tunduk terhadap perintah untuk menjalankan sesuatu dan larangan agar tidak melakukan sesuatu yang lain, atau motivasi untuk melakukan sesuatu dan imbauan agar menjauhi sesuatu yang lain. Ketundukan tersebut, didasarkan pada fakta masyarakat DIY yang agamis, sehingga telah mengajarkan kepadanya tentang bagaimana seharusnya manusia bersikap dalam setiap aspek kehidupan. Hal ini terlihat misalnya bagi orang muslim adalah dengan taat menjalankan perintah Al Qur'an dan Al Hadits dan menjauhi segala larangannya. Dalam konteks itu, maka dapat dijelaskan bahwa pada prinsipnya

16 Primantoro, Tata Nilai Budaya Yogyakarta, dalam Moch.Fatkhan, "Kearifan Lingkungan Masyararat Lereng Gunung Merapi”, Jurnal Aplikasi Ilmu-ilmu Agama, Vol. VII, No. 2, Desember 2006, hlm. 21. 
masyarakat Yogyakarta memiliki konstruksi teologis kuat akan keberadaan Allah SWT. ${ }^{17}$

Konkretisasi nilai spritual tersebut yang kemudian telah melahirkan konsep bahwa jika seseorang ingin mendapatkan keselamatan, maka harus mendekatkan diri dengan benar dan hendaklah memulainya dengan membersihkan diri dari perbuatan tercela yang terangkum dalam ma-lima atau lima, yakni mateni (membunuh), maling (mencuri), main (berjudi), madon (berzina), dan madat; mendem; mabuk (menghisap candu atau narkoba jenis apa pun dan meminum minuman keras yang dapat mengakibatkan lupa diri).

\section{Kewenangan Daerah Istimewa Yogyakarta dalam Mengatur Peredaran Minuman Beralkohol}

UU No. 32 Tahun 2004 tentang Pemerintahan Daerah memuat ketentuan pola hubungan antara Pemerintah Pusat dan Pemerintah Daerah bersifat desentralistik. Hal ini berbeda dengan pada masa Orde Baru di bawah UU No. 5 Tahun 1974 yang sentralistik atau "bias Jakarta". Desentralisasi akan didapat apabila kewenangan mengatur dan mengurus penyelenggaraan pemerintahan tidak semata-mata dilakukan oleh Pemerintah Pusat (central government), melainkan oleh kesatuan-kesatuan pemerintah yang lebih rendah yang mandiri (zelftanding), bersifat otonomi (teritorial atau pun fungsional). ${ }^{18}$

Dalam rangka penyelenggaraan hubungan kewenangan antara Pemerintah dan Daerah, UU No. 32 Tahun 2004 Pasal 10 menegaskan, Pemerintah daerah menyelenggarakan urusan pemerintahan yang menjadi kewenangannya, kecuali urusan pemerintahan yang oleh undang-undang ini ditentukan menjadi urusan Pemerintah. Urusan pemerintahan yang menjadi urusan Pemerintah meliputi: politik luar negeri, pertahanan, keamanan, yustisi, moneter dan fiskal nasional, dan agama. Dalam menyelenggarakan urusan pemerintahan tersebut di atas,

${ }^{17}$ Kenyataan masyarakat Yogyakarta di atas, misalnya tercermin dalam kehidupan rakyat Jogja yang ada di Kasongan, Bantul.Meskipun telah terkena msuibah karena adanya bencana Gempa beberapa tahun yang lalu, namun masyarakatnya tetap menerima dan berusaha bangkit. Artinya nilai religious rakyat DIY telah membumi dan sukar untuk dihilangkan. Untuk melihat fenomena tersebut, lihat selengkapnya penelitian Ali Imron dan Aat Hidayat, "Kekuatan Agama dan Kearifan Lokal dalam Proses Kebangkitan Masyarakat Yogyakarta Pascagempa", Jurnal ESENSLA, Vol. XIV, No. 1, April 2013, hlm. 105.

18 Bagir Manan, Hubungan Antara Pusat dan Daerah Menurut UUD 1945, Pustaka Sinar Harapan, Jakarta, 1994, hlm. 40. 
Pemerintah menyelenggarakan sendiri atau dapat melimpahkan sebagian urusan pemerintahan kepada perangkat Pemerintah atau wakil Pemerintah di daerah atau dapat menugaskan kepada pemerintahan daerah dan/atau pemerintahan desa. Dalam rangka menyelenggarakan urusan pemerintahan yang menjadi kewenangan daerah, pemerintahan daerah menjalankan otonomi seluas-luasnya untuk mengatur dan mengurus sendiri urusan pemerintahan berdasarkan asas otonomi dan tugas pembantuan.

Apabila melihat ketentuan dalam Pasal 13 dan Pasal 14 UU No. 32 Tahun 2004 ditegaskan urusan wajib yang menjadi kewenangan pemerintahan daerah provinsi merupakan urusan dalam skala provinsi diantaranya dan urusan wajib yang menjadi kewenangan pemerintahan daerah untuk kabupaten/kota merupakan urusan yang berskala kabupaten/kota, susugguhnya memiliki kesamaan (di luar urusan lain yang juga diperintahkan). Untuk pemerintahan daerah provinsi diantaranya memiliki kewenangan; a) penyelenggaraan ketertiban umum dan ketentraman masyarakat; b) penanganan bidang kesehatan; c) penanggulangan masalah sosial lintas kabupaten/kota. Kemudian kewenangan pemerintahan daerah untuk kabupaten/kota merupakan urusan yang berskala kabupaten/kota diantaranya meliputi; a) penyelenggaraan ketertiban umum dan ketentraman masyarakat; b) penanganan bidang kesehatan; dan c) penanggulangan masalah sosial. Dengan demikian dapat disimpulkan bahwa baik pemerintahan daerah provinsi maupun pemerintahan daerah kabupaten/kota memiliki kewajiban untuk mengatur masalah ketertiban umum dan ketentraman masyarakat; penanganan bidang kesehatan; dan penanggulangan masalah sosial.

Dalam menyelenggarakan tugas pemerintahan pada umumnya, haruslah diusahakan selalu adanya keserasian atau harmoni antara tindakan pemerintah pusat atau negara dengan tindakan daerah, agar dengan demikian kesatuan negara dapat tetap terpelihara. ${ }^{12}$ Dari penegasan yang ditentukan dalam UU No. 32 Tahun 2004, jika dikaitkan dengan perlu tidaknya daerah mengatur masalah minuman keras/minuman beralkohol sangat tergantung dari aspirasi masyarakat

12 Irawan Soejito, Pengawasan terbadap Peraturan Daerah dan Keputusan Kepala Daerah, Bina Aksara, Jakarta, 1983, hlm. 9. 
di daerah tersebut, serta kebutuhan daerah yang bersangkutan. Karena dampak yang ditimbulkan dari peredaran minuman beralkohol sangat merusak generasi muda maupun yang tua. Apalagi korban pesta minuman beralkohol 'oplosan' semakin hari semakin memprihatinkan.

\section{Payung Hukum Peredaran Minuman Beralkohol di Daerah Istimewa Yogyakarta}

Berkaitan dengan penanganan masalah minuman beralkohol, sejumlah daerah di DIY telah mengaturnya melalui peraturan daerah setempat. Akan tetapi, di Provinsi DIY hingga saat ini justru belum memiliki peraturan daerah yang mengatur masalah perdagangan, peredaran, penggunaan dan pengawasan minuman beralkohol. Selama ini Pemerintah DIY dalam melakukan pengawasan terhadap peredaran minuman beralkohol hanya mengacu kepada PP No. 8 Tahun 1962 tentang Perdagangan Barang-barang Dalam Pengawasan jo Peraturan Menteri Perdagangan RI No. 43/M-DAG/PER/9/2009 yang sudah diubah empat kali dan yang terakhir dengan Peraturan Menteri Perdagangan RI No. 54/MDAG/PER/8/2012. Tetapi setelah adanya Putusan Mahkamah Agung 18 Juni 2013 yang membatalkan dasar hukum pengaturan peredaran minuman beralkohol tersebut, maka kewenangan pengaturannya sepenuhnya menjadi kewenangan daerah.

Pasca dibatalkannya Keputusan Presiden Nomor 3 Tahun 1997 oleh Mahkamah Agung, Pemerintah pada 6 Desember 2013 kembali menerbitkan Peraturan Presiden No. 74 Tahun 2013 tentang Pengendalian dan Pengawasan Minuman Beralkohol. Di dalam konsiderans menimbang disebutkan bahwa pengaturan kembali pengendalian dan pengawasan terhadap pengadaan, peredaran, dan penjualan minuman beralkohol dimaksudkan untuk memberikan perlindungan serta menjaga kesehatan, ketertiban dan ketentraman masyarakat dari dampak buruk terhadap penyalahgunaan minuman beralkohol. Sekilas Peraturan Presiden ini hanya mengganti nama dari Keputusan Presiden yang dibatalkan oleh MA, karena materi muatan yang ada di dalamnya tidak jauh berbeda dengan aturan yang sebelumnya. 
Sejak keluarnya Putusan MA tentang pembatalan Keputusan Presiden No. 3 Tahun 1997 tentang Pengawasan dan Pengendalian Minuman Beralkohol yang dinyatakan bertentangan dengan UU No. 36 Tahun 2009 tentang Kesehatan, UU No. 8 Tahun 1999 tentang Perlindungan Konsumen dan UU No. 7 Tahun 1996 tentang Pangan, serta tidak memiliki kekuatan hukum, bukan berarti daerah kehilangan pegangan untuk mengatur masalah peredaran minuman beralkohol. Daerah melalui UU No. 32 Tahun 2004 telah diberi kewenangan untuk mengatur daerahnya secara luas. Justru dengan digugurkannya dasar hukum untuk mengatur masalah minuman beralkohol di tingkat pusat memberi kesempatan kepada daerah untuk mengaturnya sesuai kebutuhan masyarakat di daerah masing-masing. Apalagi setelah Pemerintah mengeluarkan Peraturan Presiden No. 74 Tahun 2013 tentang Pengendalian dan Pengawasan Minuman Beralkohol, Daerah dapat mengatur masalah minuman beralkohol dengan bersandar pada Peraturan Presiden tersebut.

Bagaimana dengan pemerintah DIY? Karena selama ini di DIY belum ada sandaran hukum untuk mengatur masalah pengendalian dan pengawasan minuman beralkohol, maka Pemerintah DIY dapat segera mengaturnya dalam bentuk peraturan daerah sebagai tindak lanjut kewenangan atributif yang diberikan oleh UU No. 32 Tahun 2004 jo Peraturan Presiden No. 74 Tahun 2014 tentang Pengendalian dan Pengawasan Minuman Beralkohol.

\section{Materi Muatan Peraturan tentang Peredaran Minuman Beralkohol di Daerah Istimewa Yogyakarta}

Berdasarkan kajian dan penelitian di atas, mengenai pengaturan peredaran minuman beralkohol di Provinsi Daerah Istimewa Yogyakarta, maka pokokpokok materi muatannya dirumuskan sebagai berikut.

Menurut ketentuan Peraturan Presiden No. 74 Tahun 2013, minuman beralkohol diklasifikasikan ke dalam 3 (tiga) golongan, yakni: a. Golongan A, terdiri dari semua minuman beralkohol dengan kadar etanol sampai dengan 5\% (lima perseratus); b. Golongan B, terdiri dari semua minuman beralkohol dengan kadar etanol lebih dari 5\% (lima perseratus) sampai dengan 20\% (dua puluh perseratus); c. Golongan C, terdiri dari semua minuman beralkohol dengan kadar 
etanol lebih dari 20\% (dua puluh perseratus) sampai dengan 55\% (lima puluh lima perseratus).

Minuman beralkohol golongan B dan golongan C adalah kelompok minuman keras yang produksi, importasi, pengedaran dan penjualannya ditetapkan sebagai barang dalam pengendalian. Untuk memastikan bahwa minuman beralkohol yang beredar dipasaran diketahui jenis dan kualifikasinya oleh konsumen, maka diberikan kewenangan kepada instansi yang berwenang untuk melakukan pengujian kadar etanol yang pembiayaannya ditanggung sepenuhnya oleh perusahaan.

Adapun mengenai syarat dan mekanisme bagi perusahaan atau distributor dalam memproduksi, mengedarkan, dan menjualkan minuman beralkohol kepada konsumen. Beberapa syarat dan mekanisme dimaksud adalah: (i) setiap pendirian perusahaan industri minuman beralkohol wajib memiliki izin usaha industri sebagaimana diatur dalam peraturan perundang-undangan yang berlaku. (ii) jumlah peredaran minuman beralkohol wajib memperhatikan kondisi sosial, kesehatan masyarakat dan kunjungan wisatawan. (iii) minuman Beralkohol Golongan B dan C dapat dijual langsung pada jam 20.00 s/d 02.00 WIB; (iv) penjualan Langsung Minuman Beralkohol golongan B dan C secara eceran untuk diminum di tempat hanya diijinkan di: (a) hotel berbintang 3, 4 dan 5; (b) hotel selain berbintang 3,4 dan 5 dengan jumlah pengunjung wisatawan mancanegara paling sedikit 5.000 (lima ribu) orang setiap tahun; (c) restoran dengan Tanda Talam Kencana dan Talam Selaka; dan (d) bar termasuk Pub dan Klab Malam.

Bagi daerah tertentu yang tidak memiliki satu pun tempat sebagaimana ketentuan di atas, Bupati/Walikota dengan mempertimbangkan kegiatan wisatawan mancanegara di wilayahnya, diberi kewenangan untuk menetapkan tempat tertentu lainnya bagi penjual langsung minuman beralkohol golongan $\mathrm{B}$ dan C yang berlokasi di ibukota Kabupaten/Kota atau lokasi lainnya yang ditetapkan dengan Peraturan Daerah Kabupaten/Kota.

Kewajiban bagi perusahaan untuk menyimpan minuman beralkohol di tempat-tempat tertentu guna memudahkan mengidentifikasi dan pengawasannya. Importir, distributor, sub distributor, penjual langsung 
minuman beralkohol, pengecer minuman beralkohol dan penjual langsung dan/atau pengecer minuman beralkohol untuk tujuan kesehatan wajib menyimpan minuman beralkohol di gudang yang terpisah dengan barang-barang lainnya.

Pemasukan dan pengeluaran minuman beralkohol dari gudang penyimpanan wajib dibuatkan kartu data penyimpanan yang memuat sekurangkurangnya: (i) jumlah, (ii) merek, (iii) tanggal pemasukan barang ke gudang, dan (iv) tanggal pengeluaran barang dari gudang dan asal barang.

Berkaitan dengan perizinan dan pemberian rekomendasi bagi toko yang akan melakukan Perdagangan minuman beralkohol, setiap Toko Bebas Bea (TBB) yang melakukan kegiatan usaha Perdagangan minuman beralkohol golongan B dan golongan $\mathrm{C}$ wajib memiliki SIUP-MB-TBB yang diterbitkan oleh Gubernur yang tatacara dan persyaratannya diatur lebih lanjut dengan Peraturan Gubernur. Distributor dan sub-distributor minuman beralkohol golongan B dan C di DIY yang akan mengajukan SIUP-MB kepada Menteri Perdagangan wajib Wajib mendapat rekomendasi dari Gubernur dengan cara mengajukan permohonan secara tertulis kepada Gubernur dengan melampirkan dokumen-dokumen pendukung sesuai ketentuan yang berlaku.

Kewenangan penerbitan SIUP-MB bagi Toko Bebas Bea (TBB) sebagai pengecer minuman beralkohol golongan B dan/atau C berada pada Gubernur. Toko Bebas Bea (TBB) minuman beralkohol golongan B dan/atau C yang akan mengajukan permohonan SIUP-MB harus melampirkan naskah asli dan sah beserta foto copy masing-masing 1 (satu) eksemplar yang terdiri dari: (a) Surat Penunjukan IT-MB sebagai TBB; (b) Surat Izin Tempat Usaha (SITU) khusus minuman beralkohol; (c) Surat Izin Toko Bebas Bea (TBB) dari Menteri Keuangan; (d) Surat Izin Usaha Perdagangan (SIUP) menengah atau besar; (f) Tanda Daftar Perusahaan (TDP); $(g)$ Nomor Pokok Wajib Pajak (NPWP); (h) Nomor Pokok Pengusahaan Barang Kena Cukai (NPPBKC) bagi perusahaan yang memperpanjang SIUP-MB; (i) Akta pendirian Perusahaan/ Perubahan dan oleh Departemen Hukum dan HAM untuk Perseroan Terbatas; dan (j) Realisasi pemasukan selama masa berlaku SIUP dan/atau rencana penjualan 1 (satu) tahun ke depan dari minuman beralkohol yang dijualnya. 
Toko Bebas Bea (TBB) yang berlokasi di dalam kota diizinkan menjual minuman beralkohol Golongan B dan/atau Golongan C secara eceran hanya untuk dikonsumsi sendiri kepada: a. anggota korps diplomatik yang bertugas di Indonesia beserta keluarganya yang berdomisili di Indonesia berikut lembaga diplomatik; b. pejabat/tenaga ahli yang bekerja pada Badan Internasional di Indonesia yang memperoleh kekebalan diplomatik beserta keluarganya; c. turis asing yang akan keluar dari daerah pabean; d. para pihak sebagaimana dimaksud pada huruf a, b, dan c di atas harus dibuktikan dengan passport dan/atau identitas sesuai ketentuan perundang-undangan.

Setiap pengecer minuman beralkohol: (i) Golongan A, B dan C, (ii) penjual langsung minuman beralkohol Golongan A, B dan C untuk diminum di tempat, dan (iii) pengecer minuman beralkohol Golongan A, B dan C untuk tujuan kesehatan termasuk toko obat/jamu wajib memiliki izin dari Bupati/ Walikota, yaitu: a. Surat Izin Tempat Usaha (SITU) khusus sebagai pengecer minuman beralkohol dan Izin Undang-undang Gangguan; b. Surat Izin Usaha Perdagangan (SIUP) kecil; c. Izin sebagai toko obat/jamu khusus untuk pengecer minuman beralkohol Golongan A, B dan C untuk tujuan kesehatan; dan/atau syarat untuk mendapatkan izin dari dari Bupati/ Walikota tersebut adalah melampirkan: (1) Tanda Daftar Perusahaan (TDP); (2) Nomor Pokok Wajib Pajak (NPWP); (3) Surat penunjukan sebagai pengecer minuman beralkohol dari Distributor/Sub Distributor minuman beralkohol.

Larangan untuk mengedarkan, menjual dan memproduksi minuman beralkohol berlaku bagi individu perseorangan maupun oleh perusahaan. Beberapa larangan dimaksud adalah: Setiap orang dilarang membawa, menguasai, memiliki, menyimpan dan mengkonsumsi minuman beralkohol selain di tempat yang telah ditentukan. Setiap orang dilarang memproduksi, mengedarkan, menjual dan menyediakan minuman beralkohol tanpa izin. Setiap orang pribadi atau perusahaan dilarang memproduksi, mengkonsumsi, menyimpan, menjual dan/atau mengedarkan minuman beralkohol yang tidak termasuk ke dalam golongan A, golongan B dan golongan C. Setiap orang pribadi atau perusahaan dilarang memproduksi, mengkonsumsi, menyimpan, menjual dan/atau mengedarkan minuman hasil oplosan. 
Setiap orang dilarang membawa minuman beralkohol golongan A, B dan C dari luar negeri sebagai barang bawaan, kecuali untuk dikonsumsi sendiri sebanyak banyaknya 1000 (seribu) ml per orang dengan isi kemasan tidak kurang dari 180 (seratus delapan puluh) mili.

Setiap orang dilarang menjual secara eceran minuman beralkohol golongan A dalam kemasan dan/atau menjual langsung, untuk diminum di tempat, di lokasi: (a) gelanggang remaja, kaki lima, terminal, stasiun, kios-kios kecil, penginapan remaja dan bumi perkemahan; (b) tempat yang berdekatan dengan tempat ibadah, sekolah, rumah sakit dan pemukiman; dan (c) tempat tertentu lainnya yang ditetapkan oleh Bupati/Walikota dengan memperhatikan kondisi daerah masing-masing.

Penjual Langsung Minuman Beralkohol dan pengecer minuman beralkohol, dilarang menjual minuman beralkohol golongan A, B dan/atau C kecuali kepada Warga Negara Indonesia yang telah berusia 21 (dua puluh satu) tahun yang dibuktikan dengan Kartu Tanda Penduduk dan Warga Negara Asing yang telah dewasa.

Importir, Distributor, Sub distributor, penjual langsung minuman beralkohol dan pengecer minuman beralkohol golongan $\mathrm{A}, \mathrm{B}$ dan $\mathrm{C}$ dilarang mengiklankan minuman beralkohol golongan A, B dan C. Perusahaan dilarang mencantumkan label "Halal" pada Minuman Beralkohol Golongan A, B dan C produk dalam negeri dan produk impor.

Langkah-langkah pengendalian peredaran minuman beralkohol di DIY dilakukan oleh Gubernur dengan berkoordinasi dengan Bupati/Walikota dan dibantu oleh tim yang beranggotakan dari unsur instansi terkait di Daerah. Pengendalian dalam rangka pengawasan dilakukan terhadap: (a) Pengusaha Toko Bebas Bea (PTBB), Penjual Langsung, Pengecer Minuman Beralkohol Golongan A, B dan C serta Penjual langsung dan/atau Pengecer Minuman beralkohol untuk tujuan kesehatan yang mengandung rempah-rempah jamu dan sejenisnya; (b) Perizinan, Standar Mutu, Impor, pelaksanaan pengedaran dan penjualan minuman beralkohol Golongan A, B dan C; dan (c) Tempat/lokasi pengedaran dan penjualan Minuman Beralkohol Golongan A, B dan C. 
Masyarakat diberi hak dan kesempatan untuk berpartisipasi dalam pencegahan, peredaran dan penyalahgunaan minuman beralkohol yang bertentangan dengan peraturan perundang-undangan. Adapun bentuk partisipasi masyarakat tersebut dapat berupa: (a) memberikan informasi adanya kegiatan yang dilarang dalam Perda ini; (b) memperkuat budaya lokal sebagai upaya pencegahan penyalahgunaan minuman beralkohol; (c) mengawal proses penegakan hukum Perda ini; dan (d) mengadakan penyuluhan mengenai dampak negatif dari minuman beralkohol.

Selain itu, masyarakat juga dapat melaporkan segala bentuk penyalahgunaan minuman beralkohol yang diketahuinya baik secara tertulis dan atau lisan kepada instansi yang berwenang. Untuk kepentingan ini, Pemerintah Daerah wajib membuat pusat layanan laporan masyarakat melalui media yang mudah diakses oleh masyarakat. Pemerintah daerah bekerjasama dengan pihak kepolisian wajib menjamin keselamatan masyarakat yang melaporkan penyalahgunaan minuman beralkohol.

Pihak yang mempunyai kewenangan untuk melakukan tindakan kepada setiap orang yang melanggar ketentuan dalam Peraturan Daerah ini adalah Penyidik Pegawai Negeri Sipil (PPNS).

Ketentuan sanksi apabila berbagai ketentuan mengenai peredaran minuman beralkohol ini dilangar oleh penjual. Adapun sanksinya dibagi dua yaitu sanksi administratif dan sanksi pidana. Sanksi administratif meliputi: (i) pemberian teguran tertulis, (ii) pencabutan izin; dan (iii) penutupan usaha. Sementara sanksi pidana adalah pidana kurungan paling lama 6 (enam ) bulan atau pidana denda paling banyak Rp.50.000.000,00 (lima puluh juta rupiah).

\section{Penutup}

Urgensi pengaturan peredaran minuman beralkohol (Mihol) di Daerah Istimewa Yogyakarta (DIY) dapat didasarkan pada kenyataan sebagai berikut; pertama, secara filosofis, yuridis, sosiologis dan nilai kearifan lokal yang ada di DIY sesungguhnya memiliki dasar kesamaan dan daya dukung yang kuat bahwa dalam konteks kekinian, DIY sudah selayaknya memiliki Perda terkait Peredaran 
Minuman Beralkohol. Kedua, dasar kewenangan Pemerintah DIY mengatur peredaran minuman beralkohol, setidaknya dapat didasarkan pada dimensi teoritis otonomi daerah dan dimensi yuridis melalui UU No. 32 Tahun 2004. Kemudian, melalui kewenangan atributif yang diberikan oleh UU No. 32 Tahun 2004 jo Peraturan Presiden No. 74 Tahun 2014 maka Pemerintah DIY dapat segera mengaturnya dalam bentuk peraturan daerah.

Ketiga, berdasarkan kajian dan penelitian dalam berbagai sudut pandang atau perspektif mengenai pengaturan peredaran minuman beralkohol di Provinsi Daerah Istimewa Yogyakarta, yang kemudian dapat dituangkan dalam bentuk peraturan daerah (Perda) maka pokok-pokok materi muatannya meliputi: jenis dan klasifikasi minuman beralkohol; produksi, peredaran, penjualan, dan penyimpanan minuman beralkohol; perizinan dan rekomendasi; larangan peredaran, penjualan dan produksi minuman beralkohol; serta peran serta masyarakat.

\section{Daftar Pustaka}

Ayatrohaedi, Kepribadian Budaya Bangsa (local Genius), Pustaka Jaya, Jakarta, 1986.

Dirdjosisworo, Soedjono, Alkoholisme: Paparan Hukum dan Kriminologi, Penerbit Remadja Karya, Bandung, 1984.

Farida Indrati S., Maria, Ilmu Perundang-undangan (Jenis, Fungsi dan Materi Muatan), Kanisius, Yogyakarta, 2007.

Imron, Ali dan Aat Hidayat, "Kekuatan Agama Dan Kearifan Lokal Dalam Proses Kebangkitan Masyarakat Yogyakarta Pascagempa", Jurnal ESENSIA, Vol. XIV, No. 1, April 2013.

Manan, Bagir, Hubungan Antara Pusat dan Daerah Menurut UUD 1945, Pustaka Sinar Harapan, Jakarta, 1994.

Mattulada, Sejarah Masyarakat dan Kebudayaan Sulawesi Selatan, Hasanuddin University Press, Makasar, 1991.

Moendardjito, Negara Yang Demokratis, Yayasan Koridor Pengabdian, Jakarta, 1986.

Primantoro, Tata Nilai Budaya Yogyakarta, dalam Moch.Fatkhan, "Kearifan Lingkungan Masyararat Lereng Gunung Merapi", Jurnal Aplikasi Ilmu-ilmu Agama, Vol. VII, No. 2, Desember 2006. 
Ruminiati, Modul Pendidikan Kewarganegaraan SD: Untuk Program S1 PJJ, Dirjen Dikti, Depdiknas R.I., Jakarta, 2007.

Sartini, Menggali Kearifan Local Nusantara Sebuah Kajian Filsafati, Penerbit Air Langga, Jakarta, 2003.

Shihab, Qurais, Islam dan Kesenian, Litbang PP Muhammadiyah, Yogyakarta, 1995.

Soejito, Irawan, Pengawasan terhadap Peraturan Daerah dan Keputusan Kepala Daerah, Bina Aksara, Jakarta, 1983.

Suhardi, "Preferensi Peminum Alkohol di Indonesia Menurut Riskesdas 2007", Jurnal Kesehatan, Volume 39, No. 4, 2011.

Undang-Undang Dasar Negara Republik Indonesia 1945.

Kitab Undang-undang Hukum Pidana Indonesia Indonesia, Undang-undang Nomor 23 Tahun 1992 tentang Kesehatan Indonesia, Undang-undang Nomor 32 Tahun 2004 tentang Pemerintahan Daerah Indonesia, Peraturan Presiden No. 74 Tahun 2013 tentang Pengendalian dan Pengawasan Minuman Beralkohol Peraturan Menteri Kesehatan Republik Indonesia Nomor: 86/Men.Kes/Per/IV/77 tentang Minuman Keras Peraturan Menteri Perindustrian Nomor 63/M-IND/PER/7/2014 tentang Pengendalian dan Pengawasan Industri dan Mutu Minuman Beralkohol

Koran Tempo, edisi Jum'at, 23 Agustus 2013

Dua Tewas akibat Kasus Kriminal di Jogja yang Dipicu Miras, dalam http://www.harianjogja.com/baca/2014/03/20/dua-tewas-akibat-kasuskriminal-di-jogja-yang-dipicu-miras-497479, diakses tanggal 15 Agustus 2014.

Peredaran Miras Impor Palsu Marak di Jogja, dalam http://sorotjogja.com/beritajogja-3456-peredaran-miras-impor-palsu-marak-di-jogja.html, diakses 14 Agustus 2014.

Pesta Miras Oplosan, 8 Warga Yogyakarta Tewas, dalam http://nasional.news. viva.co.id/news/read/128058-pesta_miras_oplosan_8_warga_yogyakarta_ tewas, diakses tanggal 14 Agustus 2014.

Toko Retail Modern Permudah Remaja Jogja Konsumsi Alkohol, dalam http:/ / beritajogja.co.id/2014/02/21/toko-retail-modern-permudahremaja-jogja-konsumsi-alkohol/, diakses tanggal 15 Agustus 2014.

Tiap Tahun 18.000 Orang Tewas karena Miras, dalam http://www.suarapembaruan.com/home/tiap-tahun-18000-orang-tewaskarena-miras/41095, diakses 14 Agustus 2014.

Tri Sugiarti; "Pencabutan Perda Miras: Melanggengkan Kemaksiatan", dalam www.detiknews.com, diakses 1 Juni 2014.

"Pengaruh Miras Picu Aksi Premanisme", dalam http://jogja.okezone.com/read/ 2013/04/12/510/790525/redirect, diakses 14 Juni 2014. 
96 Jurnal Hukum IUS QUIA IUSTUM NO. 1 VOL. 22 JANUARI 2015: 76 - 96

"Bentrok Warga Vs Ormas", dalam http://www.jogjatv.tv/berita/31/08/2013/bentrokwarga-vs-ormas, diakses 14 Juni 2014.

www.wikipedia.com, diakses 14 Juni 2014. 